\title{
Cultivation Studies of Verbascum thapsus $L$, the Great Mullein in Trans-Himalayan Ladakh Region
}

\author{
Phuntsog Dolkar*, Tsewang Rinchen, Diskit Dolkar and Padma Gurmet
}

National Institute for Sowa-Rigpa, Ministry of AYUSH, Union Territory of Ladakh, India

*Corresponding author

\section{A B S T R A C T}

\begin{tabular}{|l|}
\hline Ke y w o r d s \\
$\begin{array}{l}\text { Environmental } \\
\text { condition, Yield, } \\
\text { Weather data, } \\
\text { cultivation }\end{array}$ \\
\hline Article Info \\
\hline $\begin{array}{l}\text { Accepted: } \\
\text { 14 January } 2021 \\
\text { Available Online: } \\
\text { 10 February } 2021\end{array}$ \\
\hline
\end{tabular}

Trans-Himalayan region of India is known for its unique and valuable medicinal plants and Ladakh is major part of trans-himalayan. Verbascum thapsus is an important medicinal plant for traditional medicine. Present study was initiated to develop an agrotechnique for cultivation of Verbascum thapsus in three different environmental conditions that is in polycarbonate house, trench and open condition. To prepare any kind of drug, availability of raw material is indispensible. It was observed that significantly higher production of Verbascum thapsus was recorded in polycarbonate condition $1.95 \mathrm{~kg} / \mathrm{plant}$ fresh weight (whole plant weight) followed by trench $420 \mathrm{~g} / \mathrm{plant}$ and then in open air condition 370 g/plant. Similarly, other agro-morphological features were also observed to be enhanced in polycarbonate as compared to other two environments. Consequently, greenhouse condition is recommended as most suitable condition for large scale production the plant in trans-himalayan region of Ladakh. Similarly, in comparison to some reported data production of the plant was higher in open air condition in trans-himalayan cultivation may also be performed in open air condition after raising seedling in greenhouse.

\section{Introduction}

Verbascum thapsus L. belongs to Scrophulariaceae family is a biennial, or occasionally an annual plant, with a deep tap root. The plant is tall (up to $2 \mathrm{~m}$ ) stout flowering stem and a large (up to $60 \mathrm{~cm}$ in diameter) basal rosette of pubescent, oblanceolate leaves (Grieve, 1971; Whitson, 1991). Cauline leaves are elliptic-lanceolate, decurrent, gradually reduced up the stem and densely woolly with branched hairs (Millspaugh, 1974). The inflorescence is a spike-like raceme $20-50 \mathrm{~cm}$ long and approximately $3 \mathrm{~cm}$ in diameter. The sessile flowers are usually one per axial with pedicels less than $2 \mathrm{~mm}$ and slightly irregular with rotate corollas (Millspaugh, 1974). There are at least 250 known species of Verbascum of which the most important is Verbascum thapsus L. The active ingredient in Verbascum thapsus includes flavonoids like 3 methylguercitin, hesperedin and verbascoside; polysaccharides; iridoid glycosides including harpagoside; harpagide and aucubin and saponins and volatile oils (Pascual Teresa et al., 1978a; 1978b; 1980; Hattori and Hatanaka, 1958; Khuroo et al., 1988; 
Mehrotra et al., 1989; Warashina et al., 1991; 1992). Whole plant are utilized traditionally to cure various diseases like fresh leaves is used to cure migraine attacks (Bianchini and Corbetta, 1977; Lewis and Elvin-Lewis, 1977), flowers and leaves are used against inflammatory ailments in respiratory tract and others (Rodriguez-Fragoso et al., 2008), seeds are used to cure fever due to poison (Gurmet et al.,2020), roots are source for treatment of the symptoms of diabetes and its complications (McCune and Johns, 2002) aerial part are used against wound healing, urinary disease, edema (Rajbhandari et al., 2009), whole plant act as a remedy in the treatment of tuberculosis (Allen and Hatfield, 2004). Furthermore, modern scientific advancement in medicine and therapeutic potential of $V$ thapsus has been reviewed (Turker and Gurel 2005 and Raiz et al., 2013). Verbascum thapsus is used in traditional Sowa-Rigpa system of medicine of Ladakh. Sowa-Rigpa is popularly known as Tibetan medicine or Amchi medicine and it is one of the oldest surviving medical traditions of the world. The plant is known as "Yug-pagser-bye" in Sowa-Rigpa and is used for the treatment of fever in lungs, accidental bleeding, twisted ankles, dropsy and fever due to poison (Gurmet et al., 2020).

Recent interest in the developing agrotechnique for cultivation of Verbascum thapsus arises primarily because of health importance of the plant. Headache especially migraine represents a major public health problem globally. There are currently 28 million Americans with "classic" migraine headaches. In a room with 100 people, 13 are likely to have migraine (Teixido et al., 2014). Similarly a study was conducted on prevalence of headache in Kashmir Valley, India (Masoodi et al., 2016) and concluded that age distribution showed prevalence rate of migraine of $45.69 \%$ in young adults of 1945 years; females $55.44 \%$ and males $32.79 \%$.
$V$. thapsus have high potential to relieve against migraine attack if products are developed with scientific validation. For development of any product firstly available of adequate amount of raw material indispensable. Till date there are only few studies conducted on cultivation of the plant (Reinartz et al., 1984, Turker et al., 2001 and Mahmoud et al., 2014) and more research are needed to carry for easily available of the herb. Therefore, the objective of the present study was to develop an agrotechnique for cultivation of Verbascum thapsus L, using three different environmental condition that is in polycarbonate house, trench and open condition.

\section{Materials and Methods}

Cultivation of Verbascum thapsus was conducted at Model herbal garden of National Research Institute for Sowa Rigpa, LehLadakh, ministry of AYUSH, in the year 2019-2020. Seeds were collected from wild and Defence Institute of High altitude Research, Leh-Ladakh. Seedling were raised in greenhouse condition in the month of January 2019 and transplanted in field in the mid of April 2019. The whole experiment was conducted using organic fertilizer, application of sand; farm yard manure (FYM) along with the well decomposed goat, poultry manure was performed to increase the growth and yield of the plant. To get maximum growth and yield standardized FYM of 6-8 t/acre was required. The experiment was designed as a completely randomized block with three replicates of plots $\left(2 \mathrm{~m}^{2}\right.$ each). Irrigation was performed by flooding immediately after preparation of beds before transplant and kept for few days as the soil remain moist during transplanting. Field was ploughed by mixing with FYM and level the beds to get uniform water supply during irrigation. Irrigation was performed with very less water after transplanting of roots followed by seven days 
interval at later stages and whenever required. Statistical analysis was performed using oneway ANOVA (analysis of variance) with the help of 2-sided Tukey's HSD (Honestly Significant Difference) at $\mathrm{P} \leq 0.05$. All statistical analysis was performed using SPSS for Windows 17.0 version.

\section{Results and Discussion}

\section{Weather data}

Weather data was recorded in all the three environment condition (Fig 1-3). Maximum and minimum temperature, relative humidity (instrument utilized: tinytag ultra-2 hygrometer) and lux (instrument utilized:LX101A Luxmeter) in greenhouse, trench and open condition were observed. There is a major difference in weather data between three different environments especially during the cropping season. Maximum temperature was recorded in greenhouse and trench followed by open condition similarly humidity was significantly high in greenhouse and trench condition. Inversely, lux was significantly high in open condition as compared to greenhouse and trench condition.

\section{Plant growth and yield Parameters}

Different environmental condition significantly affected plant growth and yield parameters viz., plant height $(\mathrm{cm})$, number of leaves per plant, leaf length $(\mathrm{cm})$, leaf width $(\mathrm{cm})$, leaf thickness $(\mathrm{cm})$, stem diameter $(\mathrm{mm})$, root length $(\mathrm{cm})$, root thickness $(\mathrm{mm})$, root weight $(\mathrm{kg})$, number inflorescence per plant, inflorescence length $(\mathrm{cm})$, inflorescence diameter $(\mathrm{cm})$, whole plant weight (fresh weight $\mathrm{kg} / \mathrm{plant}$, seed weight per plant (g/plant) and number of seeds in 1 gram. The data in Table- 2 and 3 represents comparative growth performance of Verbascum thapsus in all the three different environmental conditions. The present result shows that plant growth and yield traits are significantly enhanced in greenhouse as compared to trench and open environmental condition. In particular, since whole plant parts are used to cure one or other health ailments hence measurement of whole plant weight (WPW) in three environmental conditions is indispensable. Whole plant weight is significantly higher in greenhouse condition as compared to trench and open condition (Table 3). In contrast to Mahmoud et al., 2014 WPW was observed to be $372 \mathrm{~g} /$ plant fresh weight in our study where as they recorded $274 / g$ per plant thus approximately $100 \mathrm{~g}$ higher weight was observed in our case. This could be due to high photoperiod observed in Ladakh region. Similarly, seed weight is another imperative parameter as seed production is directly proportional to availability of raw material for cultivation of any plant. We witness significantly higher weight of seed in greenhouse condition followed by trench and open air condition table -3 whereas no significant variation was observed in number of seeds in 1gram in all three conditions. On other hand inflorescence length was significantly higher in greenhouse followed by trench and open air condition thus it depicts that in all three environment condition seed size did not vary significantly whereas seed weight variation is due to inflorescence length. Leaf thickness is also an important traits as they reflects the adaptability of plant, thicker leaf are observed in stressful condition (Korner et al., 1986 and Dolkar et al., 2019). Thickened leaves were observed in open air condition witnessing adaptability of the plant. Our result was in contrast with Reinartz et al., 1984 who states that Verbascum thapsus grows only in full sunlight but it grows significantly better in greenhouse condition which contains half of the lux fig.3. Comparing weather data and growth parameters clearly that atmospheric condition significantly affected the growth and other parameters. To conclude 
Verbascum thapsus shows better growth in greenhouse condition followed by trench and open condition in trans-himalayan Ladakh region. Hence greenhouse condition is suggested as most suitable condition for cultivation of Verbascum thapsus in transHimalaya Ladakh region. Additionally, in current study we also observed that production of the plant was higher in open air condition as compared to reported data in same condition hence open air condition may also be utilized for agro-practice of this elite plant.

Table.1 One way-anova showing leaf vegetative parts variation in three different environmental conditions

\begin{tabular}{|c|c|c|c|c|c|c|c|c|c|}
\hline $\begin{array}{c}\text { Environmental } \\
\text { condition }\end{array}$ & $\begin{array}{c}\text { Plant } \\
\text { height }(\mathrm{cm})\end{array}$ & $\begin{array}{l}\text { Number of } \\
\text { leaves }\end{array}$ & $\begin{array}{c}\text { Leaf } \\
\text { length } \\
(\mathrm{cm})\end{array}$ & $\begin{array}{c}\text { leaf } \\
\text { width } \\
(\mathrm{cm})\end{array}$ & $\begin{array}{c}\text { leaf } \\
\text { thickness } \\
(\mathbf{m m})\end{array}$ & $\begin{array}{c}\text { Stem } \\
\text { diameter } \\
(\mathbf{m m})\end{array}$ & $\begin{array}{c}\text { Root } \\
\text { length } \\
(\mathrm{cm})\end{array}$ & $\begin{array}{c}\text { Root } \\
\text { thickness } \\
(\mathbf{m m})\end{array}$ & $\begin{array}{c}\text { Root } \\
\text { weight } \\
\text { (kg) }\end{array}$ \\
\hline Gre & $193.33 \pm 12.58$ & $38.00 \pm 5.00$ & $20.10 \pm 2.08$ & $\frac{9.87 \pm 0}{b}$ & $\underset{\mathrm{a}}{0.82 \pm 0.08}$ & $12.55 \pm 0.67^{a}$ & $\underset{\mathrm{b}}{29.33 \pm 3.06}$ & $14.40 \pm \underset{c}{0} .13$ & $\underset{\mathrm{a}}{0.37 \pm 0.01}$ \\
\hline Ope & $111.00 \pm \frac{a}{a}(0.58$ & $\underset{\mathrm{a}}{26.67 \pm 3.51}$ & $13.67 \underset{\mathrm{a}}{ \pm 0.58}$ & $\underset{\mathrm{a}}{5.90 \pm 0.85}$ & $1.11 \pm 0$ & 17.28 & $16.00 \pm \frac{a}{2} .00$ & 9.54 & $0.05 \pm \frac{a}{a} 0.01$ \\
\hline Tre & $\underset{\mathrm{a}}{123.00 \pm 11.79}$ & $\underset{\mathrm{a}}{33.33}+5.13$ & $\underset{\mathrm{b}}{21.83 \pm 3.01}$ & $9.73 \pm 1.10$ & $1.01 \pm \underset{\mathrm{b}}{ \pm 0.03}$ & $a^{13.62}$ & ${ }_{b}^{25.33 \pm 1.53}$ & ${ }_{b} 11.72 \pm 0.41$ & $0.05 \frac{\mathrm{b}}{\mathrm{b}} 0.01$ \\
\hline Total & $142.44 \pm 39.82$ & $32.67 \pm 6.34$ & $18.53 \pm 4.16$ & $8.50 \pm 2.08$ & $0.98 \pm 0.13$ & $15.48 \pm 3.70$ & $23.56 \pm 6.25$ & $11.88 \pm 2.12$ & $0.16 \pm 0.16$ \\
\hline
\end{tabular}

Table.2 One way anova showing leaf reproductive parts variation in three different environmental conditions

\begin{tabular}{|l|c|c|c|c|c|c|}
\hline $\begin{array}{c}\text { Environmental } \\
\text { condition }\end{array}$ & $\begin{array}{c}\text { Inflorescence } \\
\text { no. }\end{array}$ & $\begin{array}{c}\text { Inflorescence } \\
\text { length }(\mathbf{c m})\end{array}$ & $\begin{array}{c}\text { Inflorescence } \\
\text { diameter } \\
(\mathbf{m m})\end{array}$ & $\begin{array}{c}\text { Whole } \\
\text { plant } \\
\text { Weight (kg) }\end{array}$ & $\begin{array}{c}\text { Seed } \\
\text { weight/ } \\
\text { plant(g) }\end{array}$ & $\begin{array}{c}\text { Number of seeds } \\
\text { in 1 gram }\end{array}$ \\
\hline Greenhouse & $6.00 \pm 1.00^{\mathrm{a}}$ & $86.00 \pm 2.00^{\mathrm{b}}$ & $31.22 \pm 0.06^{\mathrm{b}}$ & $1.95 \pm 0.04^{\mathrm{b}}$ & $91.00 \pm 5.32^{\mathrm{b}}$ & $186432.00 \pm 95.50^{\mathrm{a}}$ \\
\hline Open & $2.33 \pm 0.58^{\mathrm{a}}$ & $60.00 \pm 2.00^{\mathrm{a}}$ & $23.08 \pm 0.07^{\mathrm{a}}$ & $0.37 \pm 0.00^{\mathrm{a}}$ & $28.97 \pm 6.10^{\mathrm{a}}$ & $186277.33 \pm 197.03^{\mathrm{a}}$ \\
\hline Trench & $4.00 \pm 3.46^{\mathrm{a}}$ & $65.00 \pm 2.00^{\mathrm{a}}$ & $25.67 \pm 0.06^{\mathrm{b}}$ & $0.42 \pm 0.01^{\mathrm{a}}$ & $31.15 \pm 3.53^{\mathrm{a}}$ & $186311.67 \pm 105.83^{\mathrm{a}}$ \\
\hline Total & $4.11 \pm 2.42$ & $70.33 \pm 12.07$ & $26.66 \pm 3.60$ & $0.91 \pm 0.78$ & $50.37 \pm 30.80$ & $186340.33 \pm 140.47$ \\
\hline
\end{tabular}

Fig.1-3 Weather data of greenhouse, trench and open condition

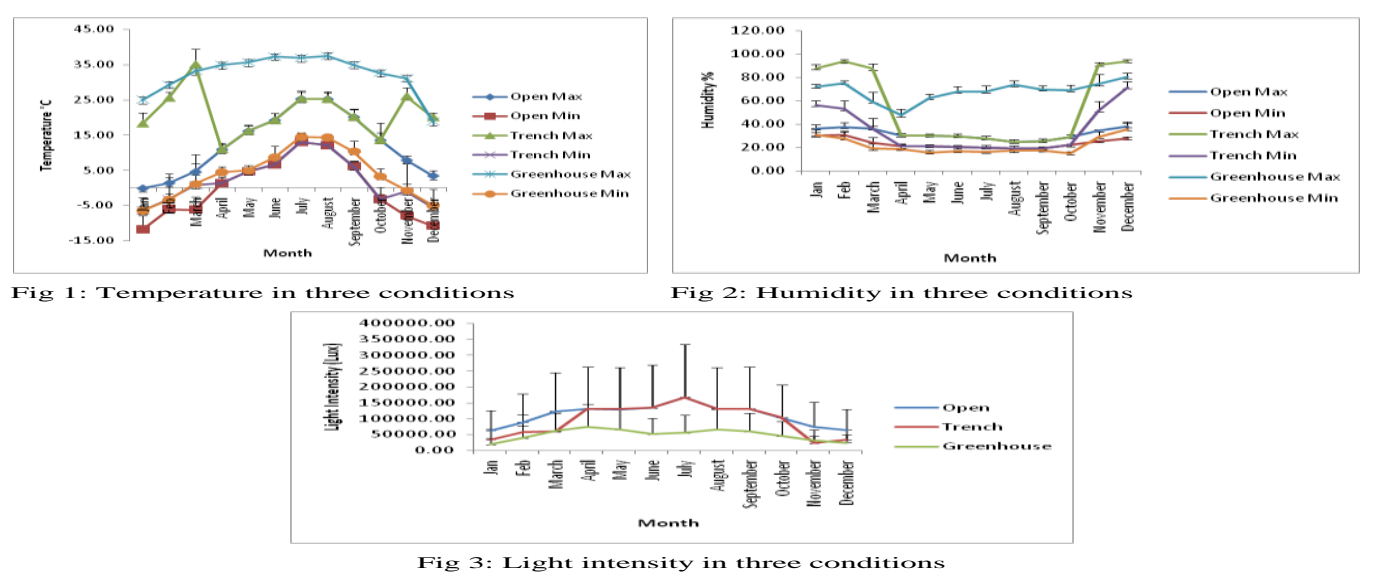


Fig.4 Pearson's correlation between different morphological characters

\begin{tabular}{|c|c|c|c|c|c|c|c|c|c|c|c|c|c|c|c|}
\hline PMC & PH & NOL & LL & LW & LT & SD & $\mathrm{RL}$ & RT & RW & $\begin{array}{l}\text { Inf } \\
\text { no. }\end{array}$ & $\operatorname{Inf} \mathrm{L}$ & Inf dia. & $\begin{array}{l}\text { WP } \\
\text { FW }\end{array}$ & SDW & NOS \\
\hline \multicolumn{16}{|l|}{$\overline{\mathrm{PH}}$} \\
\hline \multicolumn{16}{|l|}{ NOL } \\
\hline \multirow{2}{*}{\multicolumn{16}{|c|}{$\begin{array}{l}\text { LL } \\
\text { LW }\end{array}$}} \\
\hline LW & & & & & & & & & & & & & & & \\
\hline \multicolumn{16}{|l|}{ LT } \\
\hline \multirow{2}{*}{\multicolumn{16}{|c|}{ SD }} \\
\hline \multicolumn{3}{|l|}{$\mathrm{RL}$} & & & & & & & & & & & & & \\
\hline \multicolumn{16}{|l|}{$\mathrm{RT}$} \\
\hline \multicolumn{16}{|l|}{ RW } \\
\hline \multirow{2}{*}{\multicolumn{16}{|c|}{ Inf no. }} \\
\hline \multirow{2}{*}{\multicolumn{16}{|c|}{$\operatorname{Inf} \mathrm{L}$}} \\
\hline & & & & & & & & & & & & & & & \\
\hline \multicolumn{16}{|l|}{ WPFW } \\
\hline SDW & & & & & & & & & & & & & & & \\
\hline NOS & & & & & & & & & & & & & & & \\
\hline
\end{tabular}

PMC: plant morphological characters, PH: plant height $(\mathrm{cm})$, NOL: number of leaves per plant, LL: leaf length $(\mathrm{cm})$, LW: leaf width $(\mathrm{cm})$, LT: leaf thickness $(\mathrm{mm})$, SD: stem diameter $(\mathrm{mm})$, RL: root length $(\mathrm{cm}), \mathrm{RT}$ : root thickness $(\mathrm{mm}), \mathrm{RW}$ : root weight $(\mathrm{kg})$, Inf no.: number inflorescence per plant, Inf L: inflorescence length $(\mathrm{cm})$, Inf. dia: inflorescence diameter $(\mathrm{cm})$, WPFW: whole plant weight (fresh weight $\mathrm{kg} / \mathrm{plant}, \mathrm{SDW}(\mathrm{G})$ : seed weight per plant $(\mathrm{g} / \mathrm{plant})$ and number of seeds in 1 gram

\section{Pearson's correlation between plant growth and other yield parameters}

The Pearson correlation coefficient was determined to evaluate the relatedness between plant growth and other yield parameters under three different environmental conditions (Fig. 4; Supplemental Table S1; S2 and S3). As shown in Figure 4 and Supplemental Table S1, strong correlations were observed between plant growth characters under greenhouse, open and trench conditions when data sets measured in three environmental conditions. The results reveal that inflorescence length and seed weight per plant show positive correlation with plant height; root thickness, root weight, inflorescence diameter, whole plant weight show positive correlation with stem diameter, root weight, inflorescence diameter, whole plant weight show positive correlation with root thickness; inflorescence diameter, whole plant weight show positive correlation with root weight; seed weight per plant showed positive correlation with inflorescence length. The correlation data depicts an apparent result these results are related to one another. On the other hand, leaf thickness showed negative correlation with plant height; leaf thickness showed negative correlation with inflorescence length, seed weight per plant. As expected, there is huge variation in the measured plant growth traits environmental conditions, suggesting strong environment impacts on most of the traits, as shown earlier by the strong environment effect on these parameters (Table 2).

In conclusion it is observed in our study that the Verbascum thapsus cultivation was significantly higher in greenhouse condition thus greenhouse condition is suggested as most suitable condition for mass cultivation of the plant in trans-himalayan region of Ladakh. Similarly, cultivation of Verbascum thapsus may also be performed in open air condition after raising seedling in greenhouse 
as production of the plant was higher in open air condition in trans-himalayan condition as compared to some reported data. In addition research should be conducted in future for drug discovery of the plant as headache related problems are highly prevailing disease affecting large population of world.

\section{Acknowledgments}

The authors are grateful to the National Institute for Sowa Rigpa, U.T. Ladakh and Central Council for Research in Ayurvedic Sciences; Ministry of AYUSH, for providing necessary facilities and financial support.

\section{References}

Allen, D.E., Hatfield, G., 2004. Medicinal plants in folk tradition,Timber Press, Cambridge, UK .

Bianchini, F., Corbetta F. 1977. Health Plants of the World. Atlas of Medicinal Plants. Newsweek Books: New York; 60.

Gurmet, P., Stobgais, T., Yangdol, R., Lamo, T., Shridevi, V. (2020) Select flora of medicinal importance in Sowa-rigpa and ayurveda-An introductory note and pictorial exposition. CCRAS, Ministry of Ayush 1:1-409.

Grieve, M. A. Modern herbal. New York: Dover Publications; 1971.

Hattori, S., Hatanaka, S. 1958. Oligosaccharides in Verbascum thapsus L. Bot Mag (Tokyo) 71: 417-424.

Khuroo, M.A., Qureshi, M.A, Razdan, T.K, Nichols, P. 1988. Sterones, iridoids and a sesquiterpene from Verbascum thapsus. Phytochemistry 27: 35413544.

Lewis, W.H., Elvin-Lewis, M.P,F. 1977. Medical Botany. Plants Affecting Man's Health. John Wiley \& Sons: New York; 297- 299.

Mahmoud, S,M., Dein EL-G,H,M., Shleel, S.M., Darweesh, M,M. 2014. Study of
Some Factors Affected the Growth and Saponin Content in Some SaponinContaining plants and Their Bio-Activity on Japanese Quail. Middle East Journal of Applied Sciences 4:1041-1050.

Masoodi, Z,A., Shah, P,A., Iqbal, I. 2016. Prevalence of headache in Kashmir Valley, India. Neurology Asia 21,145153.

McCune, L.M., Johns, T., 2002. Antioxidant activity in medicinal plants associated with the symptoms of diabetes mellitus used by the Indigenous Peoples of the North American boreal forest. J. Ethnopharmacol. 82, 197-205.

Mehrotra, R., Ahmed, B., Vishwakarma, R.A, Thakur, R.S. 1989. Verbacoside. A new Luteolin glycoside from Verbascum thapsus. J Nat Prod 52: 640-643.

Millspaugh, C,F. 1974. American Medicinal Plants. Dover: New York; 430-434.

Pascual, Teresa, J, de., Diaz, F., Grande, M. 1978a. Components del Verbascum thapsus L. An Quim 74: 311-314.

Pascual, Teresa, J. de., Diaz, F., Grande, M. 1978b. Components del Verbascum thapsus L. II. Aceite de las semillas. An Quim 78C: 107-110.

Pascual, Teresa, J. de., Diaz, F., Grande, M. 1980. Components del Verbascum thapsus L. III. Contribution al estudio de las saponinas. An Quim 76: 107110.

Raiz, M., Haq, M,Z,U., Jaafer, H,Z,E. 2013. Common mullein, pharmacological and chemical aspects. Brazilian journal of pharmacology. 23,948-959.

Rajbhandari, M., Mentel, R., JHA, P.K., Chaudhary, R.P., Bhattarai, S., Gewali, M.B., Karmacharya, N., Hipper, M., Lindequist, U., 2009. Antiviral activity of some plants used in Nepalese traditional medicine. Evid-Based. Compl. Alt. 6, 517-522.

Reinartz, J,A. 1984. Life history variation of 
common mullein (Verbascum thapsus). Journal of Ecology 72,897-912.

Fragoso, R,L., Reyes-Esparza, J., Burchiel, S.W., HerreraRuiz, D., Torres, E., 2008. Risks and benefits of commonly used herbal medicines in Mexico. Toxicol. Appl. Pharm. 227, 125-135.

Teixido, M., and Carey, J. 2014. Migraine More than a Headache pp:1-14.

Turker, A, U., and Gurel, E. 2005. Common Mullein (Verbascum thapsus L.):
Recent Advances in Research. Phytotherapy research 19, 733-739.

Warashina, T., Miyase, T., Veno, A. 1992. Phenylethanoid and lignin glycosides from Verbascum thapsus. Phytochemistry 31: 961-965.

Whitson, T, D. (ed.). 1991. Weeds of the West. Pioneer of Jackson Hole, Jackson. Wyoming.

\section{How to cite this article:}

Phuntsog Dolka, Tsewang Rinchen, Diskit Dolkar and Padma Gurmet. 2021. Cultivation Studies of Verbascum thapsus L, the Great Mullein in Trans-Himalayan Ladakh Region. Int.J.Curr.Microbiol.App.Sci. 10(02): 404-410. doi: https://doi.org/10.20546/ijcmas.2021.1002.047 